\title{
Farkı Çevrelerde Yetiştirilen Silajık Mısır Çeşitlerinin Kuru Ot Verimi İle Bazı Kalite Özellikleri Arasındaki İlişkilerin Çeşit Özellik Biplot Analizi İle Değerlendirilmesi
}

\author{
Kağan KÖKTEN ${ }^{1} \quad$ Mahmut KAPLAN ${ }^{2} \quad$ Mevlüt AKÇURA \\ ${ }^{1}$ Bingöl Üniversitesi, Ziraat Fakültesi, Tarla Bitkileri Bölümü, Bingöl \\ ${ }^{2}$ Erciyes Üniversitesi, Ziraat Fakültesi, Tarla Bitkileri Bölümü, Kayseri \\ ${ }^{3}$ Çanakkale Onsekiz Mart Üniversitesi, Ziraat Fakültesi, Tarla Bitkileri Bölümü, Çanakkale \\ $\bowtie$ : makcura@comu.edu.tr
}

Geliş (Received): 02.11.2017

Kabul (Accepted): 15.12.2017

\begin{abstract}
ÖZET: Bu araştırma 6 çevrede ( 2 yll ve 3 lokasyon) tesadüf bloklarına göre 3 tekerrürlü olarak yetiştirilen 25 adet silajlık mısır çeşidinin kuru ot verimi (KOV) ve kuru otunda incelen 8 adet besleyicilik [Ham protein oranı (HPO), ham protein verimi (HPV), ham kül oranı (KO), nisbi yem değeri (NYD), sindirilebilir kuru madde (SKM), kuru madde tüketimi (KMT), asit deterjanda çözünmeyen lif (ADF), nötr deterjanda çözünmeyen lif (NDF)] özelliğinde çeşit x özellik ilişkileri ile özellikler arası ilişkileri belirlemek amacıyla yürütülmüştür. Özellikler arası ilişkileri görsel olarak yorumlamak amacıyla çevreler üzerinden elde edilen ortalamalar Genotip x Özellik (GÖ) biplot analiz yöntemi ile değerlendirilmiştir. Çeşit özellik biplot grafiği eksenleri denemedeki toplam varyasyonun \%80'ini açıklamıştır. Hangi çeşidin hangi özellik yönünden en iyi olduğunu belirlemek amacıyla oluşturulan biplot grafiğinde 9,13, 7, 2, 18 ve 14 nolu çeşitler köşegen çeşitler olmuştur. Bu çeşitler içerisinde 18 nolu çeşit en yüksek kuru ot verimi, en yüksek ham protein verimi ve en yüksek ham protein oranı sahip olmuştur. Köşegen olan çeşitlerden 14 nolu çeşit ise ADF, NDF, KMT, NYD ve SKM yönünden en iyi çeşit olmuştur. İncelenen özelliklerin çoğu yönünden öne çıkan 18 ve 14 nolu çeşitler kaliteli kuru ot elde etmek amacıyla yetiştirilebilecek potansiyeli taşımaktadır.
\end{abstract}

Anahtar kelimeler: Mısır, kuru ot verimi, kalite özellikleri, biplot analizi

\section{Evaluation of Relation between Dry Matter Yield and Some Quality Properties of Silage Corn Varieties Grown in Different Circles by Variety Property Biplot Analysis}

\begin{abstract}
This research was carried out to determine the relationship between varieties $\mathrm{x}$ characteristics and characteristics in 8 nutrition [Crude protein ratio (CP), crude protein yield (CPY), crude ash ratio (CA), relative feed value (RFV), digestible dry matter (DDM), dry matter intake (DMI), acid detergent fiber (ADF), neutral detergent fiber (NDF)] characteristics of 25 silage maize cultivars grown in 3 replications according to the experiment design for random blocks in 6 environments ( 2 years 3 locations). The averages obtained from the environments in order to visually interpret the interrelationships between the features were evaluated by the Genotype x Feature (GO) biplot analysis method. The variety feature biplot graphical axes explain $80 \%$ of the total variation in the experiment. In the biplot graph which was created in order to determine which kind of characteristic is best, the varieties of 9, 13, 7 , 2, 18 and 14 were diagonally varieties. Among these varieties, the variety of 18 has the highest dry matter yield, highest crude protein yield and highest crude protein ratio. The variety of 14 from diagonal varieties was the best varieties in terms of ADF, NDF, DMI, RFV and DDM. The varieties 18 and 14, which stand out most in terms of the features examined, have the potential to be cultivated to produce good quality hay.

Key words: Corn, hay yield, quality parameters, biplot analysis
\end{abstract}

\section{GiRIS}

Mısır hayvan beslenmesinde gerek yeşil olarak, gerekse silaj olarak yem zincirinde, en önemli kaba sulu yemlerden biridir (Erdal ve ark., 2009). Misir çeşitlerinin birim alandan yüksek verime sahip olmaları, hasadının kolay olması, lezzetli ve hayvanlar tarafindan sevilerek tüketilmesi (Neylon ve Kung, 2003; Kaplan, 2005) yüksek adaptasyon kabiliyetine sahip olmaları ve beslenme değerlerinin yüksek olması gibi özellikleri nedeniyle, dünyada ve Türkiye'de en önemli silajlık yem bitkileri durumundadırlar (McDonald ve ark., 1991; Meeske ve ark., 1993).

Mısırda çevresel farklılıklar, çeşit ve genetik özellikler verim ve kalite üzerine oldukça etkilidir (Budakli Carpici ve ark., 2010). Çok çevrede kurulan denemelerde en önemli amaç çok sayıda özelliği inceleyerek, bu özellikler yönünden hedef çevrelere en uygun genotipi belirlemektir (Yan ve Rajcan, 2002). Çok çevrede yetiştirilen çok sayıda genotipte incelenen çok sayıda özelliğin etkin ve doğru bir şekilde değerlendirilmesi için geliştirilen yöntemler içinde en yaygın kullanılan yöntem biplot analizleridir (Yang ve ark., 2009). Yemler arasında görülen farklılıkların ortaya konulmasinda, yemlerin kimyasal kompozisyonu ile enerji ve sindirilebilir besin maddelerinin belirlenmesi oldukça önemlidir (Canbolat, 2012).

$\mathrm{Bu}$ araştırma 6 çevrede yetiştirilen (2 yil ve 3 lokasyon) 25 silajlı mısır çeşidinde incelenen kuru ot verimi ham protein oran1, ham protein verimi, ham kül oranı, nisbi yem değeri, sindirilebilir kuru madde, kuru madde tüketimi, asit deterjanda çözünmeyen lif, nötr deterjanda çözünmeyen lif özelliklerinin çeşit x özellik 
ilişkileri ile özellikler arası ilişkileri belirlemek amac1yla yürütülmüştür.

\section{MATERYAL ve METOT}

Alt1 çevrede yürütülen denemelerde 25 adet misır çeşidi materyal olarak kullanılmıştır. Denemede materyal olarak kullanılan silajlık misır genotipleri ve bu genotiplerin sağlandığ kurum ve kuruluşlar Çizelge 1'de verilmiştir. Denemeler farklı rakımlara sahip Diyarbakır-Bismil (rakım 535 m), Bingöl (rakım 1153 m) ve Elazı̆ (rakım $1070 \mathrm{~m}$ ) illerinde kurulmuştur. Araştırma 2014 ve 2015 yıllarının yetiştirme sezonunda tesadüf blokları deneme desenine göre 3 tekerrürlü olarak yürütülmüsştür. Tohumlar $5 \times 2.8 \mathrm{~m}$ genişliğindeki parsellerde $70 \times 15 \mathrm{~cm}$ mesafede ekilmiştir. Denemelere ekim öncesi toprak analizine göre $80 \mathrm{~kg} \mathrm{ha}^{-1} \mathrm{~N}, 80 \mathrm{~kg}$ $\mathrm{ha}^{-1} \mathrm{P}_{2} \mathrm{O}_{5}$ ve $80 \mathrm{~kg} \mathrm{ha}^{-1} \mathrm{~K}_{2} \mathrm{O}$ gübresi verilmiştir. Daha sonra bitkiler 50-60 $\mathrm{cm}$ uzunluğuna ulaştıklarında ara çapası ile birlikte ve tepe püskülü çıkarma dönemleri olmak üzere yine iki kez üst gübre olarak toplamda 150 $\mathrm{kg} \mathrm{ha}^{-1} \mathrm{~N}$ gübresi verilmiştir. Bitkilere gelişme dönemi boyunca 2 defa çapa ve 1 defa da boğaz doldurma işlemleri yapılmış ve tarla kapasitesine göre haftada bir defa sulanmıştır. Denemelerin yapıldı ğı illere ait bazı iklim ve toprak özellikleri Çizelge 2'de verilmiştir.

Çizelge 1. Misır çeşitleri ile temin edildiği firma ve kurumlar

\begin{tabular}{llllll}
\hline No & \multicolumn{1}{c}{ Çeşit } & Firma adı & No & \multicolumn{1}{c}{ Çeşit } & \multicolumn{1}{c}{ Firma adı } \\
\hline 1 & 31 P41 & Pioneer & 14 & DİAN & Panam \\
2 & 30 B74 & Pioneer & 15 & MARVIN & Panam \\
3 & 31 Y43 & Pioneer & 16 & ELDORA & Panam \\
4 & 31 A34 & Pioneer & 17 & WAYNE & Venturoli \\
5 & $12-219$ & Panam & 18 & ŞAFAK & Batı Akdeniz Tarımsal Araştırma \\
6 & $12-218$ & Panam & 19 & BATEM EFE & Bat1 Akdeniz Tarımsal Araştırma \\
7 & $12-231$ HO & Panam & 20 & TUONO & Beta Agriculture and Trade Co. \\
8 & DKC 955 & Monsanto & 21 & BURAK & Batı Akdeniz Tarımsal Araştırma \\
9 & DKC 6903 & Monsanto & 22 & SEME KUKURUZA & Zemun Polje \\
10 & DKC 6589 & Monsanto & 23 & SEME KUKURUZA & Zemun Polje \\
11 & DKC 7211 & Monsanto & 24 & ADV 2898 & Limagrain \\
12 & DKC 6590 & Monsanto & 25 & TRUVA & Limagrain \\
13 & R.U 4 HD & Pioneer & & & \\
\hline
\end{tabular}

Çizelgede de görüldüğü gibi her üç ilde de ilk yıl yetiştirme döneminde düşen yağış miktarı ikinci yıl yetiştirme dönemine göre daha yüksek saptanmıştır. Çalışma alanlarının tınlı toprak bünyesine sahip olduğu, Diyarbakır ve Elazığ illerindeki deneme alanlarına ait toprak pH'sinın hafif alkali (7.73 ve 7.78 , sirasiyla),
Bingöl ilindeki deneme alanlarına ait toprak pH'sının ise hafif asidik (6.37) olduğu tespit edilmiştir. Diyarbakır ve Elazı̆̆ deneme alanlarındaki kireç içeriğinin orta düzeyde Bingöl deneme alanında ise düşük düzeyde olduğu belirlenmiştir.

Çizelge 2. Tarla denemeleri ile ilgili bilgiler

\begin{tabular}{cccccl}
\hline \multicolumn{2}{c}{ Çevre / Sezon } & $\begin{array}{c}\text { Yükseklik } \\
\text { (m.a.s.l.) }\end{array}$ & Yağış (mm) & Sulama* & \multicolumn{1}{c}{ Toprak } \\
\hline Diyarbakır & 2014 & 535 & 110.7 & $100 \times 4$ & $\mathrm{pH}=7.73$ Killi, orta kireçli \\
Elazı̆ & 2014 & 1070 & 121.5 & $100 \times 4$ & $\mathrm{pH}=7.78$ Killi, orta kireçli \\
Bingöl & 2014 & 1153 & 135.8 & $100 \times 4$ & $\mathrm{pH}=6.37$ Killi, düşük kireçli \\
Diyarbakır & 2015 & 535 & 67.2 & $100 \times 4$ & $\mathrm{pH}=7.73$ Killi, orta kireçli \\
Elazı̆ & 2015 & 1070 & 64.8 & $100 \times 4$ & $\mathrm{pH}=7.78$ Killi, orta kireçli \\
Bingöl & 2015 & 1153 & 96.6 & $100 \times 4$ & $\mathrm{pH}=6.37$ Killi, düşük kireçli \\
\hline
\end{tabular}

* denemeler ihtiyaç duyulduğunda salma sulama ile dört kez tarla kapasitesinde sulanmıştır.

Tüm mısır çeșitleri süt-hamur olum dönemine (\%30 kuru madde) ulaştı̆̆ zaman, her parselin kenar tesiri (kenar iki sıra ile parsel başından $50 \mathrm{~cm}$ 'lik kısım) dışında kalan ortadaki iki sıranın toprak yüzeyinden el ile biçilmesi suretiyle hasat yapılmıştır. Bitki örnekleri tartılarak yeşil ot (silaj) verimleri $\mathrm{kg} / \mathrm{da}$ olarak belirlenmiştir. Yeşil otlardan alınan numuneler $70^{\circ} \mathrm{C}$ 'de sabit ağılığa gelinceye kadar kurutulup tartılmış ve $\mathrm{kg}$ $\mathrm{da}^{-1}$ olarak hesaplanmıştır. Örneklerde kurutma tamamlandıktan sonra mısır örnekleri $1 \mathrm{~mm}$ elek çapına sahip değirmende öğütülerek kimyasal analizler için hazırlanmıştır. Ham protein ve ham kül analizleri AOAC (1990)'da belirtilen yöntemlerle yapılmıştır. Hücre duvarını oluşturan NDF ve ADF analizleri sirasiyla Van Soest ve Wine (1967) ve Van Soest (1963)'de belirtilen yöntemle yapılmıştır. Sindirilebilir kuru madde (SKM), kuru madde tüketimi (KMT) ve nispi yem değerleri (NYD) de hesaplanarak 
bulunmuştur. Hesaplamalarda aşağıdaki formüller kullanılmıştır (Morrison, 2003).

$\mathrm{SKM}=88.9-(0.779 \times \mathrm{ADF})$

$\mathrm{KMT}=120 / \mathrm{NDF}$

$\mathrm{NYD}=(\mathrm{SKM} \times \mathrm{KMT}) / 1.29$

6 çevrede ( 2 yıl ve 3 lokasyon) tesadüf bloklarına göre 3 tekerrürlü olarak yetiştirilen 25 adet silajlık misır çeşidinin kuru ot verimi (KOV) ve kuru otunda incelen 8 adet besleyicilik [Ham protein oranı (HPO), ham protein verimi (HPV), kül oranı (KO), nispi yem değeri (NYD), sindirilebilir kuru madde (SKM), kuru madde tüketimi (KMT), asit deterjanda çözünmeyen lif (ADF), nötr deterjanda çözünmeyen lif (NDF)] özelliğinde çeşit $\mathrm{x}$ özellik ilişkileri ile özellikler arası ilişkileri korelasyon analizi ve GÖ-biplot analizi ile değerlendirilmiştir (Yan ve Kang, 2003; Yan, 2014). Özellikler arası ilişkileri görsel olarak yorumlamak amacıyla üç farklı GÖ-biplot grafiği oluşturulmuştur. İstatistiki analizlerin tamamı GGE-biplot programında yapılmıştır (Yan, 2014).

\section{BULGULAR ve TARTIŞMA}

Araştırmamızda 6 çevrede yetiştirilen 25 adet hibrit mısır çeşidinde kuru ot verimi ile birlikte incelenen 8 adet kalite özelliğine ait ortalamalar Çizelge 3'te verilmiştir. İncelenen özelliklere ait ilişkileri açıklamak amacıyla ortalama değerler kullanılarak oluşturulan, biplot grafikleri Şekil 1, 2 ve 3 de verilmiştir.

Çevre ortalamalarına göre oluşturulan Genotip özellik biplot grafiği Şekil 1 de verilmiştir. Silajlık misır yetiştiriciliğinde en önemli konulardan birisi elde edilen kuru otta kalite özelliklerinin değerlendirilmesidir (Garibay ve ark., 1997). Genotip özellik biplot grafikleri hangi genotipin hangi özellik yönünden öne çıktığını görsel olarak yorumlamak amacıyla oluşturulmaktadır (Yan, 2014). Genotiplerin ortalamalarına göre grafik beş bölüme ayrılmıştır. Birinci ve ikinci bölümde herhangi bir özellik yer almazken, üçüncü bölümde dört özellik, dördüncü bölümde iki özellik, beşinci bölümde ise 3 özellik yer almıştır. Araştırma materyalinden 6 adet çeşit köşegen genotipler olarak, grafik üzerinde konumlanmışlardır. 2 nolu çeşit KOV, KO, ADF ve NDF özelliklerinin yer aldığı bölümde köşegen genotip olurken, 18 nolu çeşit HPO ve HPV'nin yer aldığ bölümde köşegen çeşit, 14 nolu çeşit ise KMT, NYD ve SKM özelliklerinin yer aldığı bölümde köşegen genotip olmuştur. Mısırın kimyasal bileşiminin değişiminde iklim faktörleri çok etkilidir. Ortalama sıcaklık, nispi nem, yağış miktarı ve güneşlenme süresi gibi iklim özellikleri kimyasal yapıyı değiştirmektedir (Zhang ve ark., 2016). Sicaklık değişimi yaprak alanında ve hücre çeperinde değişimler (ADF ve NDF), gelişme geriliği veya artışı (Galdamez-Cabrera ve ark., 2002; Mahajan ve Tuteja, 2005) gibi hücrede birçok değişikliklere neden olmaktadır. İncelenen özelliklerden KO, ADF ve NDF'nin hayvan besleme açısından düşük olması istenmektedir (Kaplan ve ark., 2014). Dolayısıyla ADF ve NDF oranlarındaki artış DMD, DMI and RFV değerlerini düşürmektedir (Kaplan ve ark., 2015) Bu nedenle bu üç özellik bakımından en düşük değerlere sahip olan 14 ve 6 nolu çeşitlerin diğer çeşitlerden üstün olduğu değerlendirilmesi yapılmıştır. İncelenen diğer özelliklerde ise yüksek değerlere sahip olan çeşitler diğerlerinden üstün olmuştur. Bu özellikler yönünden üstün olan çeşitler, grafik üzerinde yakın konumda yer almışlardır.

Çizelge 3. Araştırmada incelen özelliklere ait bazı istatistiki terimler ile özellikler arasındaki korelasyon katsayıları $(n=25)$

\begin{tabular}{|c|c|c|c|c|c|c|c|c|c|c|c|c|}
\hline \multirow[b]{2}{*}{ Öz. } & \multicolumn{4}{|c|}{ İstatistik Parametreler } & \multicolumn{8}{|c|}{ Özellikler } \\
\hline & Ort & St. S. & Min & Max & KOV & HPO & HPV & KO & NYD & SKM & KMT & ADF \\
\hline $\begin{array}{l}\text { KO } \\
\text { V }\end{array}$ & 2224.0 & 214.9 & 1930 & 2797 & & & & & & & & \\
\hline HPO & 6.7 & 0.3 & 6.2 & 7.4 & -0.07 & & & & & & & \\
\hline HPV & 149.3 & 15.0 & 122.7 & 185.8 & $0.81 * *$ & $0.47 *$ & & & & & & \\
\hline KO & 5.1 & 0.5 & 4.2 & 6.2 & $0.44 *$ & -0.31 & 0.17 & & & & & \\
\hline $\begin{array}{l}\text { NYD } \\
\text { SK }\end{array}$ & 133.9 & 10.7 & 106.6 & 154 & $-0.39 *$ & 0.18 & -0.14 & $\begin{array}{l}0.65 * * \\
-\end{array}$ & & & & \\
\hline $\begin{array}{l}\mathbf{M} \\
\mathbf{K M}\end{array}$ & 68.0 & 2.0 & 61.8 & 71.1 & -0.38 & 0.04 & -0.18 & $\begin{array}{l}0.55 * * \\
-\end{array}$ & $0.93 * *$ & & & \\
\hline $\mathbf{T}$ & 2.5 & 0.1 & 2.2 & 2.8 & -0.32 & 0.27 & -0.05 & $0.65 * *$ & $\begin{array}{l}0.95 * * \\
-\end{array}$ & $\begin{array}{l}0.82 * * \\
-\end{array}$ & & \\
\hline ADF & 26.8 & 2.6 & 22.8 & 34.8 & 0.38 & -0.04 & 0.18 & $0.55 * *$ & $\begin{array}{l}0.93 * * \\
-\end{array}$ & $\begin{array}{l}0.97 * * \\
-\end{array}$ & $\begin{array}{l}-0.81 \\
-\end{array}$ & \\
\hline NDF & 49.5 & 2.7 & 45.2 & 57.1 & $0.44 *$ & -0.28 & 0.15 & $0.65 * *$ & $0.96 * *$ & $0.85^{* *}$ & $0.96 * *$ & $0.85 * *$ \\
\hline
\end{tabular}

KOV: kuru ot verimi (kg/da), HPO: ham protein oranı (\%), HPV: ham protein verimi (kg/da), KO: kül oranı (\%), NYD: Nispi yem değeri, SKM: Sindirilebilir kuru madde (\%), KMT: Kuru madde tüketimi (\%), ADF: Asit deterjanda çözünen lif (\%), NDF (Nötr deterjanda çözünen lif (\%), *: $\mathrm{P}<0.05, * *: \mathrm{P}<0.01$ 


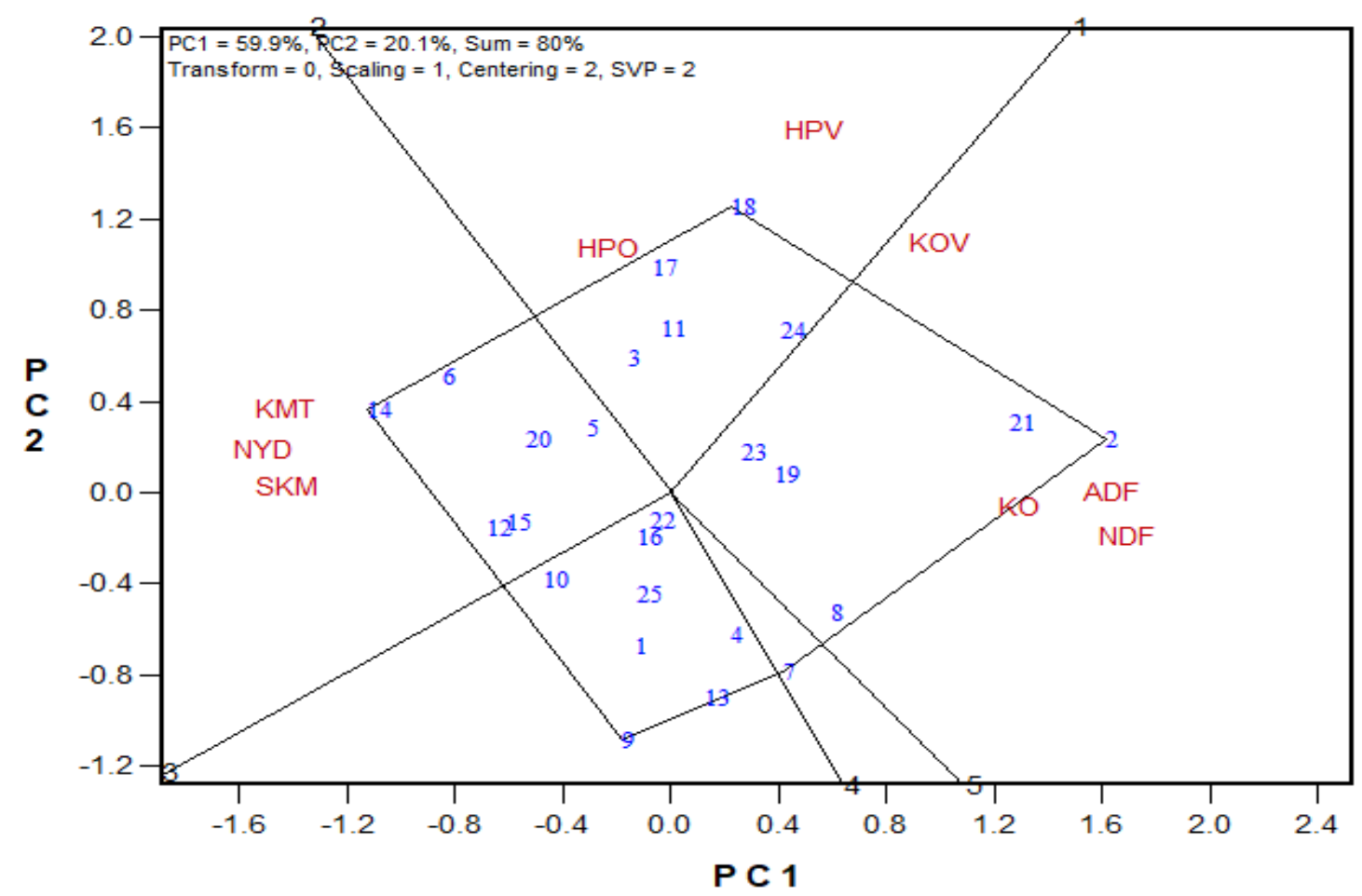

Şekil 1. Çevreler üzerinden mısır çeşitlerinde incelenen özelliklere ait genotip x özellik biplot grafiği

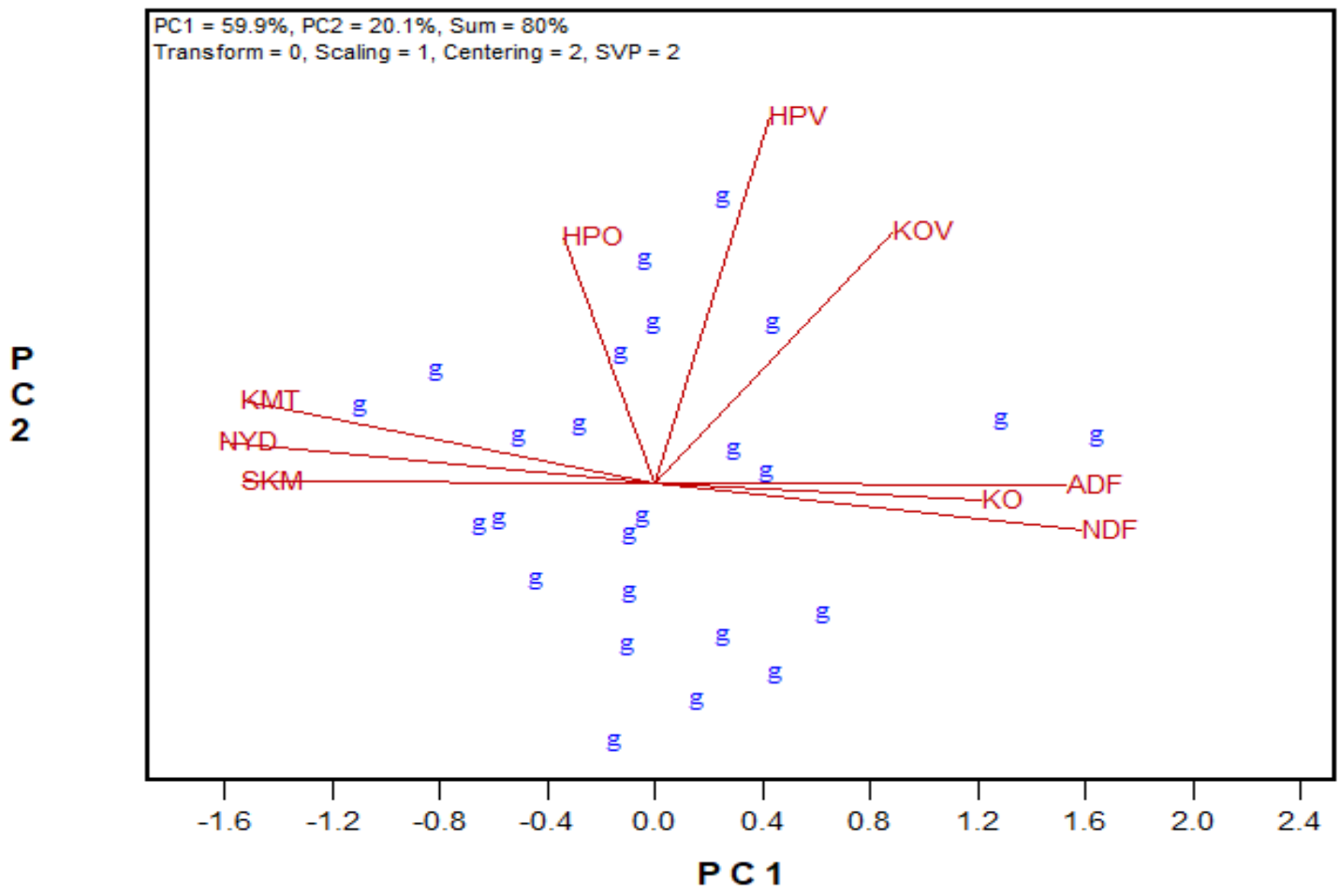

Şekil 2. Mısır çeşitlerinde incelenen özellikler arası ilişkilere ait biplot grafiği

Örneğin, 18 nolu çeşit HPO, HPV ve KOV yönünden diğer çeşitlerden üstün olurken, 9 nolu çeşit bu üç özellik yönünden düşük değerlere sahip olmuştur. Benzer şekilde, 14 ve 6 nolu çeşitler KMT, NYD ve SKM yönünden diğer çeşitlerden üstün olmuştur. Ham protein oranlarının çeșitler arasında farklı olması bitkinin genetik yapısından kaynaklandığı gibi yaprak, başak ve gövde oranları, olgunlaşma dönemine, sıcaklığa, gübrelemeye ve çevresel faktörlere göre değiştiğini ifade edilmektedir (Ball ve ark., 2001). Genotiplerde ADF ve NDF oranlarının farklı olması bu özellikler ile hesaplanan KMT, NYD ve SKM değişikliğe neden olmaktadır.

Araştırmada incelenen özelliklere ait bazı istatistiki parametreler ile özellikler arası korelasyon katsayıları Çizelge 3'de, özellikler arası ilişkilere ait biplot grafiği 
Şekil 2 de verilmiştir. Özellikler arası ilişkiyi görsel olarak değerlendirmek için oluşturulan biplot grafiğinde, aralarında olumlu ve yüksek korelasyon bulunan özellikler arasındaki açı daralmakta, söz konusu bu özellikler birbirlerine yakın konumda yer almaktadır (Akçura, 2011). İncelenen özelliklerden KO ile ADF ve NDF arasinda, SKM ile NYD ve KMT arasında olumlu ve önemli korelasyonlar tespit edilmiştir (Çizelge 3, Şekil 2). Ayrıca, KOV ile HPV arasında olumlu ve önemli korelasyon belirlenirken, KOV ile HPO arasında ise olumsuz ve önemsiz korelasyon belirlenmiştir. Özellikler arasında olumsuz ve önemli korelasyonlar ise, KMT ile KO, ADF ve NDF arasında; NYD ile KO, ADF ve NDF arasında; SKM ile $\mathrm{KO}, \mathrm{ADF}$ ve NDF arasında tespit edilmiştir (Çizelge 3, Şekil 2).

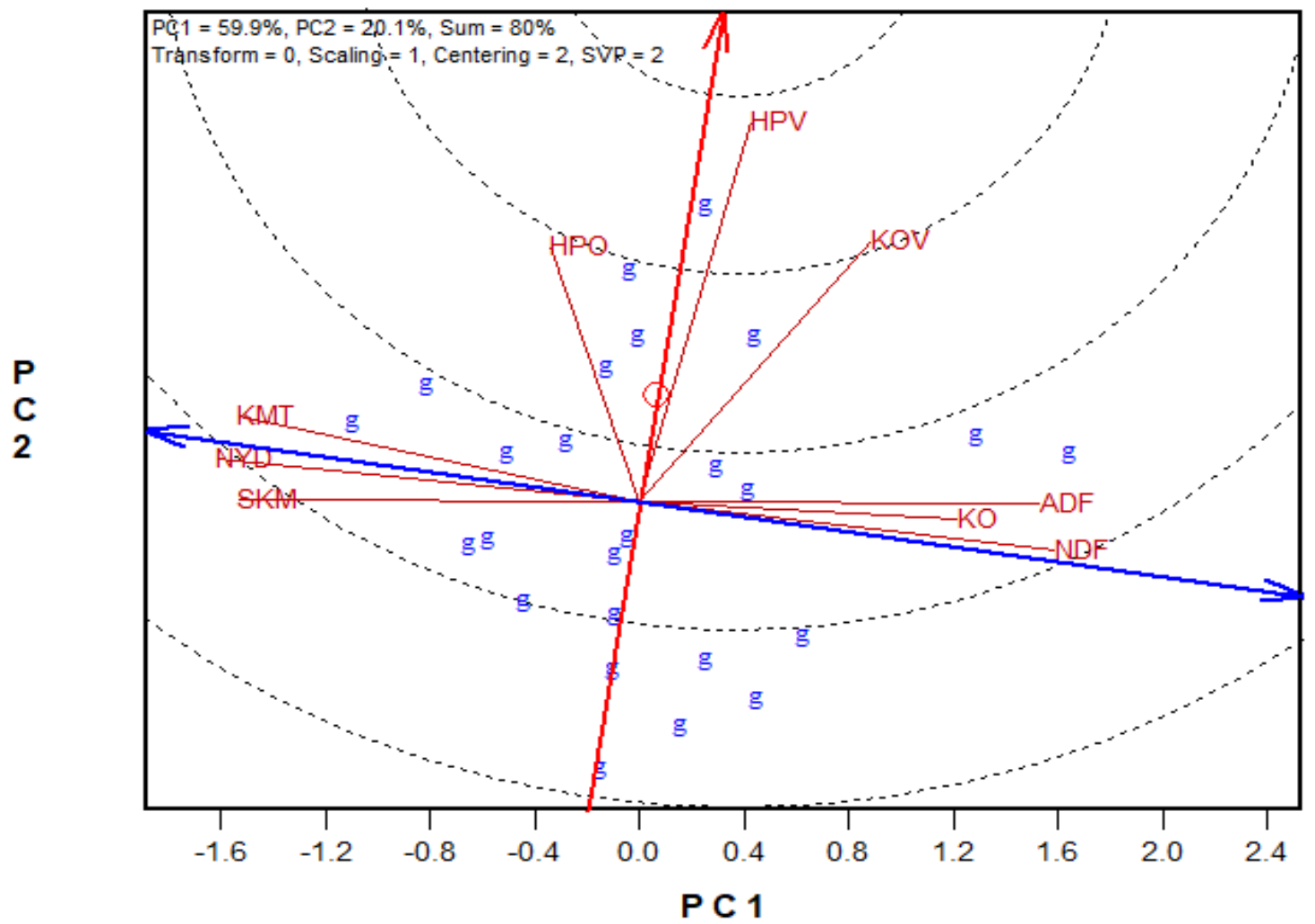

Şekil 3. Mısır çeşitlerinde incelenen özelliklere ait ideal özellik için oluşturulan biplot grafiğgi

Biplot analiz yönteminin önemli özelliklerinden birisi, incelenen özelliklerden hangisi yada hangilerinin genotip performansını en iyi şekilde tespit edilmesine olanak sağlamasıdır (Yan ve Kang, 2003). Bu bakış açıcına göre oluşturulan biplot grafiğinde ortalama özellik eksenine göre oluşturulan çemberlere göre özellikler değerlendirilmektedir (Akçura ve Kökten, 2017). Bu amaçla oluşturan biplot grafiği Şekil 3'de verilmiştir. Özellikler arasında ideal özelliğe en yakın olan özellik, HPV olurken, bu özelliği KOV ve HPO takip etmiştir.

\section{SONUÇ}

Faklı çevrelerde yetiştirilen mısır çeşitlerinden elde edilen kuru otta 8 adet kalite özelliği arasındaki ilişkilerin incelendiği bu araştırmanın sonuçlarına göre;

a) Misır çeşitlerinde incelenen özellikler arasındaki ilişkileri görsel olarak değerlendirmek amacıyla GÖ biplot analiz yöntemi etkin bir şekilde kullanilabilir,

b) Misır otunda incelen özelliklerden yüksek oranda olumlu korelasyona sahip olanlar içerisinden bir tanesinin incelenmesi yeterli olabilir, c) KMT, NYD ve SKM özelliklerinden bir tanesinin; $\mathrm{KO}, \mathrm{ADF}$ ve NDF özelliklerinden bir tanesinin incelenmesi yeterli olacaktır.

\section{KAYNAKLAR}

Akcura M, Kokten K 2017. Variations in grain mineral concentrations of Turkish wheat landraces germplasm. Quality Assurance and Safety of Crops \& Foods, 9(2): 153-159.

Akçura M 2011. The relationships of some traits in Turkish winter bread wheat landraces. Turkish Journal of Agriculture and Forestry, 35(2): 115-125.

AOAC 1990. Official method of analysis. Association of official analytical chemists 15 th.edition, pp.66-88.

Ball DM, Collins M, Lacefield GD, Martin NP, Mertens DA, Olson KE, Putnam DH, Undersander DJ, Wolf MW 2001. Understanding forage quality. American Farm Bureau Federation Publication, Park Ridge, IL.

Budakli Carpici E, Celik N, Bayram G 2010. Yield and quality of forage maize as influenced by plant density and nitrogen rate. Turkish Journal of Field Crops, 15(2): 128-132. 
Canbolat O 2012. Comparison of in vitro gas production, organic matter digestibility, relative feed value and metabolizable energy contents of some cereal forages. Kafkas Universitesi Veteriner Fakultesi Dergisi, 18(4): 571-577.

Erdal S, Pamukcu M, Ekiz H, Soysal M, Savur O, Toros A 2009. The determination of yield and quality traits of some candidate silage maize hybrids. Mediterranean Agricultural Sciences, 22(1): 75-81.

Galdamez-Cabrera NW, Coffey KP, Coblentz WK, Turner JE, Scarbrough DA, Johnson ZB 2002. Effect of nitrogen fertilization on effective ruminal disappearance of dry matter, fiber and selected macro-minerals from common bermudagrass harvested on two different dates. Arkansas Animal Science Department Report Series, 499: 41-44.

Garibay SV, Stamp P, Ammon HU, Feil B 1997. Yield and quality components of silage maize in killed and live cover crop sods. European Journal of Agronomy, 6(3-4): 179-190.

Kaplan M 2005. Effects of different intra and inter row spacing on yield and yield components of second crop silage maize (Zea mays L.) under Kahramanmaras conditions. University of Kahramanmaras Sutcu Imam Institute of Natural and Applied Science Department of Field Crops. MSc Thesis.

Kaplan M, Kamalak A, Kasra AA, Güven I 2014. Effect of maturity stages on potential nutritive value, methane production and condensed tannin content of Sanguisorba minor Hay. Kafkas Universitesi Veteriner Fakültesi Dergisi, 20: 445-449.

Kaplan M, Yilmaz MF, Kara R 2015. Variation in hay yield and quality of new triticale lines. Journal of Agricultural Sciences, 21: 50-60.
Mahajan S, Tuteja N 2005. Cold, salinity and drought stresses: An overview. Archives of Biochemistry and Biophysics, 444: 139-158.

McDonald P, Henderson AR, Heron SJE 1991. The Biochemistry of Silage. Second Edition. 340 p. Chalcombe Publication.

Morrison JA 2003. Hay and Pasture Management, Chapter 8. Extension Educator, Crop Systems Rockford Extension Center.

Neylon JM, Kung L 2003. Effects of cutting height and maturity on the nutritive value of corn silage for lactating cows. Journal of Dairy Science, 86: 21632169.

Van Soest PJ, Wine RH 1967. The Use of Detergents in the Analysis of Fibrous Feeds. IV. Determination of Plant Cell Wall Constituents. JAOAC, 50: 50-55.

Van Soest PJ 1963. The Use of Detergents in the Analysis of Fibrous Feeds. II. A rapid method for the determination of fiber and lignin. JAOAC, 46, 829-835.

Yan W 2014. Crop variety trials: Data management and analysis. John Wiley \& Sons.

Yan W, Kang MS 2003. GGE Biplot Analysis: A graphical tool for breeders, geneticists, and agronomists. Boca Raton, FL: CRC Press.

Yan W, Rajcan, IR 2002. Biplot analysis of test sites and trait relations of soybean in Ontario. Canadian Journal of Plant Science, 42: 11-20.

Yang RC, Crossa J, Cornelius PL, Burgueño J 2009. Biplot analysis of genotype $\times$ environment interaction: Proceed with caution. Crop Science, 49(5): 1564-1576.

Zhang L, Li YK, Li ZC, Li QF, Lyu MB, Li DF, Lai CH 2016. The nutritive values in different varieties of corn planted in one location fed to growing pigs over three consecutive years. Asian Australians. Journal of Animal Science, 29(12): 1768-1773. 